\title{
THE PROBLEMS OF CRIMINALIZATION OF THE SIMILAR CRIMES INVOLVING THREATS TO PUBLIC HEALTH (ARTICLE 8 OF THE COUNCIL OF EUROPE CONVENTION ON THE COUNTERFEITING OF MEDICAL PRODUCTS AND SIMILAR CRIMES INVOLVING THREATS TO PUBLIC HEALTH)
}

D0I: 10.36740/WLek202012206

\author{
Pavlo S. Berzin', Ivan S. Demchenko², Anzhela B. Berzina ${ }^{2}$ \\ 'DEPARTMENT OF CRIMINAL LAW POLICY AND CRIMINAL LAW, TARAS SHEVCHENKO NATIONAL UNIVERSITY OF KYIV, KYIV, UKRAINE \\ 2DEPARTMENT OF FORENSIC MEDICINE AND MEDICAL LAW, BOGOMOLETS NATIONAL MEDICAL UNIVERSITY, KYIV, UKRAINE
}

\begin{abstract}
The aim: Medicrime Convention is a first international treaty against counterfeit medical products and similar crimes involving threats to public health. There are problems in criminalization of those acts that are listed in Art. 8 of the Medicrime Convention because the term of "similar crimes" is absent in the current criminal legislation of Ukraine. Materials and methods: The conducted study is based on the analysis of the provisions of the Medicrime Convention, the criminal legislation of Ukraine. The following methods: dialectical method; hermeneutic method; system-and-structural method; comparative-and-law method were used.

Results: Comparison of the provisions of the Medicrime Convention allows to state that crimes in its Articles 5-8 that are different from those provided for in Art. 5-7 of this Convention and form independent types of actions, are at least "placing on the market" of medicinal products and medical devices provided in subparagraph "a" of paragraph 1 of Art. 8 and "commercial use of original documents" specified in subparagraph "b" of paragraph 1 of Art. 8.

It's an assumption that Art. 5-8 of the Medicrime Convention provide for such independent types of crimes involving threats to public health as: 1) manufacturing of counterfeit medical products, active substances, excipients, parts, materials and accessories as well as medicinal products, medical devices, active substances and excipients; 2) the supplying, the offering to supply, the brokering, the trafficking, the keeping in stock, importing and exporting of counterfeit medical products, active substances, excipients, parts, materials and accessories; 3 ) the making of false documents or the act of tampering with documents; 4) placing on the market of medicinal products, medical devices; 5) the commercial use of false documents.

Conclusions: The term of "similar crimes" in Art. 8 of the Medicrime Convention covers multi-ordinal intentional acts that constitute different types of independent crimes involving threats to public health, as well as special kinds of some of them. These types of crimes are not the same (identical).
\end{abstract}

KEY WORDS: Elements of crime, Falsified medical products, Medicrime Convention, Health Care, Public Health

Wiad Lek. 2020;73(12 p. II):2733-2736

\section{INTRODUCTION}

On $28^{\text {th }}$ October 2011, the Council of Europe Convention on the counterfeiting of medical products and similar crimes involving threats to public health (hereinafter referred to as the "Medicrime Convention" [1] was signed on behalf of Ukraine. Medicrime Convention is a first international treaty against counterfeit medical products and similar crimes involving threats to public health. According to Art. 5-8 of the Medicrime Convention, each Party shall take the necessary legislation and other measures to establish as offenses under its domestic law a) the intentional manufacturing of counterfeit medical products, active substances, excipients, parts, materials and accessories, falsification of medicinal products, medical devices, active substances and excipients (paragraphs 1, 2 of Article 5 of the Medicrime Convention), b) when committed intentionally, the supplying or offering to supply, including brokering, the trafficking, including keeping in stock, importing and ex- porting of counterfeit medical products, active substances, excipients, parts, materials and accessories (paragraph 1 of Article 6 of the Medicrime Convention), (c) the making of false documents or the act of tampering with documents, when committed intentionally (paragraph 1 of Article 7 of the Medicrime Convention), and (d) the so-called "similar crimes involving threats to public health" (Article 8 of the Medicrime Convention). Crimes provided in Art. 5-7 of the Medicrime Convention are generally referred to as "manufacturing of counterfeits" (Article 5), "the supplying, offering to supply and trafficking in counterfeits" (Article 6) and "falsification of documents" (Article 7) in the names of these articles of the Medicrime Convention.

There are problems in defining the range of those crimes (criminal offenses), which are currently provided for in the Criminal Code of Ukraine (hereinafter referred to as CC), but are similar to those specified in Art. 5-7 of the Medicrime Convention [2, p. 28], as well as the criminal- 
ization of those acts that are listed in Art. 8 of the Medicrime Convention because the term of "similar crimes" is absolutely absent in the current criminal legislation of Ukraine. It should be mentioned that provisions of Article 8 (namely par. a(i)) relate to the criminal law protection of intellectual property relations, which is indirectly related to public health issues. [3]

The lack of solutions to these problems not only hinders the fulfilment of the mentioned conditions of the Medicrime Convention, but also makes ineffective mechanisms for preventing crimes related to counterfeiting of medical products and other crimes involving threats to public health. The ineffectiveness of the use of some of these mechanisms was once emphasized in the Concept of implementation of state policy to prevent counterfeiting of medical products, approved by the order of the Cabinet of Ministers of Ukraine of April 3, 2019 No.301-r. At the same time, the solution of these problems in the science of criminal law of Ukraine is mainly to formulate a scientific model of the criminal law mechanism to prevent crimes defined in the Medicrime Convention [4, pp.856-861], the need to ensure clarity of the conceptual apparatus and interpretation of criminal legislation of Ukraine, unity of law enforcement practice and efficiency of realization of norms of the criminal legislation of Ukraine which requires appropriate amendments to the Criminal Code of Ukraine, their justification, scientific confirmation and empirical proof $[5$, p.6].

\section{THE AIM}

An adequate understanding of the term of "similar crimes" should be offered, types of crimes (criminal offenses) provided for in the Criminal Code of Ukraine and are similar to those defined in Art. 5-7 of the Medicrime Convention should be identified, as well as which acts listed in Art. 8 of the Medicrime Convention still not provided for in the CC of Ukraine as crimes (criminal offenses) of certain types and thus "fall out" of criminalization should be found out based on the specifics in Art. 8 of the Convention on Medicrime acts included in the term of "similar crimes involving threats to public health", and taking into account the analysis of the relevant provisions of the CC of Ukraine.

\section{MATERIALS AND METHODS}

The conducted study is based on the analysis of the provisions of the Medicrime Convention, the criminal legislation of Ukraine. The following methods: dialectical method - while clarifying the nature of similar crimes involving threats to public health, and determining the content of components of such crimes under the Criminal Code of Ukraine; hermeneutic method - while interpreting of basic terms and their constructions, as well as formulating of offers to improve the norms of the CC; system-and-structural method - while substantiating the systemic criminal law protection of public health; comparative-and-law method - while determining the common and different provisions in the provision of similar crimes involving threats to pub- lic health, in the Medicrime Convention and the criminal legislation of Ukraine were used to achieve this purpose.

\section{RESULTS AND DISCUSSION}

1. Problems of marking the relevant social-and-legal phenomena with adequate terms and interpretation. The term "Similar crimes involving threats to public health" [6] is used in English in the official text of the Medicrime Convention which in the official Ukrainian-language text of the Convention is translated as "подібні злочини, що загрожують охороні здоров'я” [7]. Thus, when translating the text of the Medicrime Convention, the English term "similar" was translated into Ukrainian as "подібні" and as "схожі" into Russian which cannot be considered an unambiguous and accurate method of legislative technique, especially given the different meanings of these terms.

The English-language term of "similar" should be interpreted taking into account the similarity, the identity of something [8]. However, there is no such unambiguity while interpreting of the Ukrainian-language term of "подібний" because this term is used in two different meanings: 1 ) the presence of common features, properties with something; 2) sameness.

Thus, a problem of replacing the term of "подібні злочини" in the Ukrainian-language text of the Convention translation with another term (for example, "тотожні злочини") reflecting the ambiguity inherent to the term of "similar" arises. The solution to this problem and the use of the necessary terminology depends on the special-and-legal level of use of the term of "подібні злочини", which can be seen below.

2. Special-and-legal level of solving the problem of using the term of "similar crimes" (“подібні злочини") in legal acts.

2.1. The term of "similar crimes" in Art. 8 of the Medicrime Convention is used to specify activities committed intentionally, in so far as such an activity is not covered by Articles 5-7 of this Convention as offenses, but have the following types: 1) the manufacturing, the keeping in stock for supply, importing, exporting, supplying, offering to supply or placing on the market of: medicinal products without authorisation where such authorisation is required under the domestic law of the Party; or medical devices without being in compliance with the conformity requirements, where such conformity is required under the domestic law of the Party; 2) the commercial use of original documents outside their intended use within the legal medical product supply chain, as specified by the domestic law of the Party.

2.2. The following should be considered at the ratio of the types of "similar crimes" defined in Art. 8 of the Medicrime Convention and the types of those crimes provided in Art. 5-7 of this Convention:

a) "manufacturing" (its subject is medicinal products and medical devices) provided for in subparagraph "a" of paragraph 1 of Art. 8 is a special kind of "manufacturing", which is specified in paragraph 1 of Art. 5 of the Convention and the subject of which is "counterfeit medical 
products, active substances, excipients, parts, materials and accessories", as well as medicinal products, medical devices, active substances, excipients, parts, materials mentioned in paragraph 2 of Art. 5;

b) "the keeping in stock for supply, importing, exporting, supplying, offering to supply" (their subject is medicinal products and medical devices) entrenched in subparagraph "a" of paragraph 1 of Art. 8 is a special kind of such actions as defined in paragraph 1 of Art. 6 "the supplying or the offering to supply, including brokering, the trafficking, including keeping in stock, importing and exporting" (the subject of these actions is "counterfeit medical products, active substances, excipients, parts, materials and accessories");

c) "placing on the market" of medical products and medical devices should be considered an independent type of crime which is defined in subparagraph "a" of paragraph 1 of Art. 8 and does not form a special type specified in paragraph 1 of Art. 5 of the Convention "manufacturing";

d) "the commercial use of original documents" provided for in subparagraph "b" of paragraph 1 of Art. 8 in connection with the indication of "outside their intended use" is an independent type of crime and does not form a special kind of "the making of false documents or the act of tampering with documents" provided for in paragraph 1 of Art. 7.

Thus, a comparison of the mentioned provisions of the Medicrime Convention allows us to state that crimes in its Articles 5-8 that are different from those provided for in Art. 5-7 of this Convention and form independent types of actions, are at least "placing on the market" of medicinal products and medical devices provided in subparagraph "a" of paragraph 1 of Art. 8 and "commercial use of original documents" specified in subparagraph " $b$ " of paragraph 1 of Art. 8.

Therefore, it should be assumed that Art. 5-8 of the Medicrime Convention provide for such independent types of crimes involving threats to public health as: 1) manufacturing of counterfeit medical products, active substances, excipients, parts, materials and accessories as well as medicinal products, medical devices, active substances and excipients; 2) the supplying, the offering to supply, the brokering, the trafficking, the keeping in stock, importing and exporting of counterfeit medical products, active substances, excipients, parts, materials and accessories; 3 ) the making of false documents or the act of tampering with documents; 4) placing on the market of medicinal products, medical devices; 5) the commercial use of false documents.

\section{CONCLUSIONS}

The term of "similar crimes" in Art. 8 of the Medicrime Convention covers multi-ordinal intentional acts that constitute different types of independent crimes involving threats to public health, as well as special kinds of some of them. These types of crimes are not the same (identical). From this point of view, the use of the Ukrainian-language term "подібні" in the translation of the official text of the Medicrime Convention is quite justified.

2.3. When comparing these types of crimes under Art. 5-8 of the Medicrime Convention, and their corresponding kinds with the types of crimes defined in the Special Part of the CC of Ukraine it should be taken into account the following.

1) intentionally illegal production of medicinal products, as well as purchasing, transportation, sending, storage for selling purposes or sale of intentionally illegal medicinal products provided for in Art. 321-1 of the CC of Ukraine, in principle, is consistent with the requirements of Art. 5, 6,8 of the Medicrime Convention;

2) falsification of documents provided for in Art. 7 of the Medicrime Convention, as well as the commercial use of original documents relating to the falsification of medicinal products referred to in subparagraph "b" of paragraph 1 of Art. 8 of this Convention, are not directly (textually) singled out in the articles of the Special Part of the CC of Ukraine, but may be covered by the relevant provisions of Art. 358 ("Forgery of documents and use of forged documents") and Art. 366 ("Forgery in office") of the CC.

3) the CC of Ukraine does not contain criminalization of the manufacturing, the keeping in stock for supply, importing, exporting, supplying, offering to supply or placing on the market of medical devices, which is specified in subparagraph "a" of paragraph 1 of Art. 8 of the Medicrime Convention

2.4. The disadvantage of using the term of "similar crimes" ("подібні злочини") in the legal act, which is the source of criminal law of Ukraine, is that it indicates an analogy of the application of criminal law, which is prohibited. That is, the prohibition of the so-called "analogy of law" (analogia legis). This prohibition is indicated in part 4 of Art. 3 of the CC of Ukraine. In addition, the legal guidelines for prohibiting the analogy of the application of criminal law are requirements of the definition of criminality and punishment provided for in Part 2 of Art. 4 of the CC of Ukraine, as well as other criminal law consequences of the act only of the CC of Ukraine. Therefore, the norms of the General and Special Parts of the CC, which define a specific type of crime, its individual kinds, types and sizes of punishments and other measures of criminal law nature, cannot be applied to monotypic factual situations which are not provided by these criminal law norms. Thus, the content of the analogy of its application prohibited in the CC of Ukraine is limited and "is narrowed" to its specific norms, which determine the criminality, punishment of the act and its other criminal consequences provided for in part 2 of Art. 4 of the CC of Ukraine.

Prohibition of the application of the criminal law by analogy prevents the "creation" of a new legal (regulatory) basis for determining the criminality and punishment of the act, as well as its other criminal consequences. Only specific norms of the CC are recognized by such basis according to part 2 of Art. 4 of the CC. Instead, if the current CC did not prohibit (allow) analogy in the application of its provisions, there would be at least two legal grounds 
on which an act not directly provided for by the CC as a crime would be recognized as a specific type of the crime or its separate kind and entailed the application of a certain type of punishment or other measures of a criminal law character. The first such basis would be the relevant norms of the CC, which defined a particular type of crime or its particular kind and established the type and amount of punishment or other measures of criminal law character for its commission, and the second legal basis would be the relevant provision authorizing the application of the CC by analogy (such provision would in fact mean the possibility of establishing the criminality and punishment of the act, as well as other criminal consequences in monotypic situations, which are not directly provided for "within" the first basis). Thus, the prohibition of analogy in establishing the criminality and punishment of the act and its other criminal consequences should apply both to the norms of the Special Part of the CC and to the provisions of the so-called "regulatory laws" and subordinate legislation, if the norms of the Special Part of the CC have blanket dispositions and provide for the use of the provisions of such "regulatory laws" and subordinate legislation [9, pp. 135-136; 10, p. 51].

\section{REFERENCES}

1. Pro ratifikaciyu Konvenciya Radi Evropi pro pidroblennya medichnoi produkcii ta podibni zlochini, shcho zagrozhuyut' ohoroni zdorov'ya [Ratification of the Council of Europe Convention on Counterfeiting of Medical Devices and Similar Crimes Threatening Health] Law of Ukraine, dated 7.06.2012 No 4908-VI. Vidomosti Verhovnoi Rady. 2013; 17: 160 [reviewed 2020.08.12] (Ua).

2. TacijV., Tyutyugin V., Borisov V. etal., Kriminal'ne pravo Ukrainy:Zagal'na chastina: pidruchnik; za red. V.YA. Taciya, V.I. Tyutyugina, V.I. Borisova. 6-te vid., pererob. i dopov. [Criminal Law of Ukraine: textbook] Harkiv: Pravo, 2020.584 p. (Ua).

3. Demchenkol.,Soloviov 0. Poperedzhennya poshyrennya fal'syfikovanykh likars'kykh zasobiv na mizhnarodnomu ta natsional'nomu rivni [Preventing the spread of counterfeit medicines at the international and national levels] Kyiv: Novyi Druk, 2014. 128 p. (Ua).

4. Gutorova N., Zhytnyi 0., Soloviov 0. Falsification of medical Products: criminal law mechanism combating threats to public Health. Wiadomości Lekarskie 2019; tom LXXII, nr. 5, cz. I:856-861.

5. Kovalenko I.A. Kriminal'na vidpovidal'nist' za fal'sifikaciyu ta obig fal'sifikovanih likars'kih zasobiv: disertaciya na zdobuttya naukovogo stupenya kand. yurid. nauk [Criminal liability for falsification and trafficking counterfeitmedicines:Manuscript]. Odesa: Nacional'nijuniversitet"Odes'ka yuridichna akademiya" MON Ukrainy, 2017.257 p. (Ua).

6. Council of Europe Convention on the counterfeiting of medical products and similar crimes involving threats to public health. Available from: https://www.coe.int/en/web/conventions/full-list/-/conventions/ rms/090000168008482f [reviewed 2020.08.12]
7. Konvenciya Rady Evropy pro pidroblennya medichnoi produkcii ta podibni zlochini, shcho zagrozhuyut' ohoroni zdorov'ya. [Council of Europe Convention on Counterfeiting of Medical Devices and Similar Crimes Threatening Health] Oficijnij visnik Ukraïni. 2012; № 50; № 96: 608; 49; 1954 (Ua).

8. Cambridge Dictionary Available from: https://dictionary.cambridge. org/ru/словарь/английский/similar [reviewed 2020.08.12] (Ru).

9. Berzin P.S. Kriminal'ne pravo. Zagal'na chastina: pidruchnik u3-ht. -T. I.Zagal'nizasadi-2-ge vid., viprav. ta dop. [Criminal Law: General Part]. Kiiiv:VD «Dakor», 2019: 135-136 (Ua).

10. Navroc'kij V.0. Princip zaboroni analogiï i jogo diya pri zastosuvanni Kriminal'nogo kodeksu Ukraïni 2001 roku. [The principle of prohibition of analogy and its effect in the application of the Criminal Code of Ukraine] Novij Kriminal'nij kodeks Ukraïni: Pitannya zastosuvannya i vivchennya: Mater. mizhnar. nauk.-prakt. konf. Harkiv 25-26 zhovt. 2001 r. [New Criminal Code of Ukraine: issues of application and study: materials of the international scientific-practical conference in Kharkiv 0ctober 25-26, 2001] Redkol.: Stashis V.V. (golov. red.) ta in. Kyiv - Kharkiv.: "YUrinkom Inter", 2002: 51 (Ua).

\section{ORCID and contributionship:}

Pavlo S. Berzin: 0000-0003-4146-7910 A, D, F

Ivan S. Demchenko: 0000-0001-8721-2775 B, D, E

Anzhela B. Berzina: 0000-0002-9885-309X ${ }^{B, D}$

\section{Conflict of interest:}

Authors declare no conflict of interest.

\section{CORRESPONDING AUTHOR Ivan S. Demchenko \\ Forensic Medicine and Medical Law Department, Bogomolets National Medical University Tarasa Shevchenko boulevard, 13, Kiev, Ukraine 01601 tel: +380503102281 \\ e-mail:demchenko.ivan@gmail.com}

Received: 17.08 .2020

Accepted: 30.11 .2020

A - Work concept and design, B - Data collection and analysis, C - Responsibility for statistical analysis, D-Writing the article, $\mathbf{E}-$ Critical review, $\mathbf{F}$ - Final approval of the article 